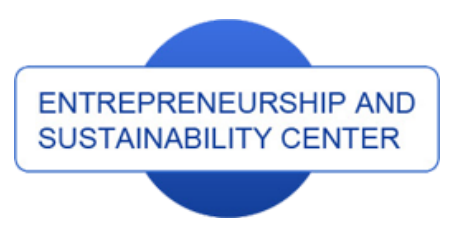

Publisher

http://jssidoi.org/esc/home

\title{
ENTREPRENEURIAL ENVIRONMENT AT REGIONAL LEVEL: THE CASE OF POLISH PATH TOWARDS SUSTAINABLE SOCIO-ECONOMIC DEVELOPMENT
}

\author{
Michal Barnard Pietrzak ${ }^{1}$, Adam P. Balcerzak ${ }^{2}$, Artur Gajdos ${ }^{3}$, Lukasz Arendt $^{4}$ \\ ${ }^{1,2}$ Nicolaus Copernicus University, Faculty of Economic Sciences and Management, ul. Gagarina 13a, 87-100 Toruń, Poland \\ ${ }^{3}$ University of Lodz, Faculty of Economics and Sociology, ul. Rewolucji 1905 r. 37 90-214 Lodz, Poland \\ ${ }^{4}$ University of Lodz, Faculty of Economics and Sociology, P.O.W. 3/5, 90-255 Lodz, Poland \\ E-mails: ${ }^{1}$ pietrzak@umk.pl, ${ }^{2}$ adam.balcerzak@umk.pl, ${ }^{3}$ gajdos@uni.lodz.pl, ${ }^{4}$ larendt@uni.lodz.pl
}

Received 15 July 2017; accepted 24 October 2017; published 29 December 2017

\begin{abstract}
Globalization process creates fovurable conditions for dynamic development of economic centers both at national and regional level. Yet, it may be an obstacle for growth for peripheral countries and regions. In the European Union one can confirm convergence process at national level. However, in Central European countries the convergence of national economies does not support sustainable growth at regional level and regional convergence process. This situation often leads to the problem of draining up of scarce resources from peripheral regions, which negatively affects their entrepreneurship potential and sustainable socio-economic development. In the longer run this unbalanced spatial growth can become a significant obstacle for welfare improvements. In this context, the purpose of the article is to analyze the quality of entrepreneurial environment in Poland at regional level within the context of sustainability framework. The research was done for NUTS 2 regions in the years 2010-2014. The quality of entrepreneurial environment is considered here as a multiple-criteria phenomenon that should be treated as a latent variable. Thus, in the research Structural Equation Modeling (SEM) analysis was applied. Values of the latent variable were assessed based on confirmatory factor analysis, which provided information on the socio-economic development of Polish regions, which determinates the entrepreneurial conditions. In order to group the regions to homogenous subsets natural breaks method was used. The conducted research confirms the process of improvement of entrepreneurial conditions in most of the NUTS 2 regions in Poland. From the perspective of regional convergence process, on the one hand, one can point some positive factors such as noticeable improvements in some underdeveloped regions. However, the dominance of the central region and significant disparities between the NUTS 2 are still relatively stable and extensive. From the methodological perspective the article shows the applicability of SEM methodology to national and regional analysis with application of data from national statistics.
\end{abstract}

Keywords: Entrepreneurial environment, entrepreneurship at regional level, multiple-criteria analysis, Structural Equation Modeling (SEM), regional sustainability, Poland

Reference to this paper should be made as follows: Pietrzak, M.B.; Balcerzak, A. P.; Gajdos, A.; Arendt, Ł 2017. Entrepreneurial environment at regional level: the case of Polish path towards sustainable socio-economic development, Entrepreneurship and Sustainability Issues 5(2): 190-203. http://doi.org/10.9770/jesi.2017.5.2(2)

JEL Classifications: C30, C38, O14, Q01 


\section{Introduction}

Entrepreneurship level is currently considered as one of the most important intangible growth factors in developed countries. It is crucial for building competitive knowledge-based economy. In spite of the fact that the global markets are dominated by multinational corporations in most of the Euopean countries more than $50 \%$ of employment and national product are created by small and medium sized enterprises. Thus, in the reality of growing international competition, entrepreneurship is crucial for building effective economy both at national and regional level (Agrawal, 2016; Adamowicz \& Machla, 2016; Pietrzak \& Balcerzak, 2016a; Saeed et al. 2017; Kljucnikov \& Belas, 2016; Mayer et al. 2016; Yan et al., 2017; Melas et al., 2017). This factor is commonly pointed in many national strategies of growth and it was strongly stressed in the Europe 2020 plan. It is an immanent part of socio-economic sustainability or sustainable development concepts and it is crutial for reaching the objectives of improving social capital in an economy (Davis, 2008; Kuc, 2014; Czarniewski, 2016; Strielkowski et al., 2016 Zemlickienè et al, 2017). In the case of countries and regions at the average level of development, which must overcome the risk of middle income trap, the high level of entrepreneurship activity and good quality of entrepreneurial environment, next to high quality of human capital or bulding of effective network infrastructure (Agenor et al., 2012; Balcerzak, 2016a; Kondratiuk-Nierodzińska, 2016; Pietrzak \& Balcerzak, 2016b; Żelazny \& Pietrucha, 2017; Gajdos, 2014; Gajdos, Żmurkow-Poteralska 2012), are commonly believed to be a condition for overcoming the thread of middle income trap and improving the chances for higher pace of convergence process (Agenor \& Canuto, 2015).

However, it is believed that globalization process and international integration of economies create favourable conditions for more dynamic development mostly for economic centers both at national and regional level. In the same time these both factors tend to be an obstacle for growth for peripheral countries and regions. These factors are confirmed for European economy, where in the case of European Union empirical research proofs convergence at national level. On the other hand, in many countries the convergence of national economies does not support socio-economic sustainable growth at regional level, which would lead to regional convergence process (Kuc, 2017a; 2017b). This situation often leads to the phenomenon of draining up of the most valuable resources from the peripheral regions, which negatively affects their entrepreneurship potential and sustainable socio-economic environment. In the longer run this unbalanced spatial growth can become a significant obstacle for improving macroeconomic growth and welfare of national economies.

In the above mentioned context the main objective of the article is to propose a method and to measure the quality of entrepreneurial environment at regional level in Poland in the years 2010-2014. Polish economy can be considered as an interesting case study for the proposed scientific problem, as it is the biggest economy in Central Europe that is considered to be an example of relatively effective transformation from centrally-planned to market-oriented economy. Poland has been able to take advantage of convergence process with the developed European economies, but it is currently considered as a country facing the problem of middle income trap. Thus, improving the quality of enterprenerial environment at regional level is currently considered as one of the main objectives of regional policy for Polish government.

The entrepreneurial environment is analyzed here as a multiple-criteria latent phenomenon within the context of sustainable development objectives and socio-economic sustainability framework. As a result, Structural Equation Modeling (SEM) methodology was used here.

The paper is organized as follows. In the next section the methodology of the Structural Equation Modeling used for assessing the measure of quality of entrepreneurial environment is presented. In this part the assumptions applied in the process of selecting potential diagnostic variables are given. This section is finished with presentation of hypotheses for empirical part. The next part is devoted to the presentation of the empirical model and assessing its statistical quality. Then, the two following sections concentrate on the analysis of the obtained 
ENTREPRENEURSHIP AND SUSTAINABILITY ISSUES

ISSN 2345-0282 (online) http://jssidoi.org/jesi/

2017 Volume 5 Number 2 (December)

http://doi.org/10.9770/jesi.2017.5.2(2)

results in regard to changes of ratings and groupings of the regions in the analyzed period. Finally, the paper ends with the conclusions, discussion of its limitations and prospects for two potential directions for future research.

\section{Assumptions, methodology and hypothesis of the empirical research}

Based on the literature review regarding factors influencing entrepreneurial activity and entrepreneurial environment there are two main assumptions of the empirical contribution. First of all, it is assumed that the entrepreneurial conditions, especially at the regional level, are strictly related to the socio-economic development of regions (Barkowiak-Bakun, 2017; Pietrzak, 2017). This assumption was crucial from the perspective of selection of potential diagnostic variables. Then, from the perspective of the possibilities of measurement of the quality of entrepreneurial environment at regional level, it was assumed that it should be considered as a multiplecriteria latent variable (see: Kawiorska 2016; Knatko et al. 2016; Mayer et al., 2016; Kot et al. 2016; Balcerzak, 2016b; Ključnikov et al., 2016; Dobeš et al., 2017; Ivanova, 2017; Balcerzak \& Pietrzak, 2017).

Based on the above mentioned assumptions, it was possible to apply Structural Equation Modeling (SEM) in the analysis (Loehlin 1987; Bollen, 1989; Kaplan, 2000; Brown, 2006). SEM methodology is commonly used in the empirical research, which is based on the survey data (see Kooshki \& Zeinabadi, 2016; Ebrahimi \& Mirbargkar, 2017; Kozubíková et al. 2017; Smaliukienè et al., 2017). However, it can be also effectively used in the case of research that is based on aggregated macroeconomic or regional data coming from public official statistics (Pietrzak et al., 2012; Balcerzak \& Pietrzak 2016a; 2016b). When the research is limited to the identification process and measurement of latent variables, SEM methodology enables to conduct confirmatory factor analysis. In that case only the external model (measurement model) is applied, which can be given with equations 1 and 2:

$$
\begin{aligned}
& \mathbf{y}=C_{\mathbf{y}} \boldsymbol{\eta}+\boldsymbol{\varepsilon}, \\
& \mathbf{x}=\mathbf{C}_{\mathbf{x}} \xi+\boldsymbol{\delta},
\end{aligned}
$$

where:

$\boldsymbol{\eta}$ - the vector of endogenous latent variables,

$\xi$ - the vector of exogenous latent variables,

$\mathbf{y}, \mathbf{x}$ - the vector of observable variables,

$\mathbf{C}_{\mathbf{y}}, \mathbf{C}_{\mathbf{x}}$ - matrices of factor loadings,

$\boldsymbol{\varepsilon}, \boldsymbol{\delta}$ - measurement error vectors.

The parameters of the model are usually estimated with application of maximum likelihood method, generalized least squares method and asymptotically distribution-free method. In the case of the normal distribution for the observable diagnostic variables the maximum likelihood method should be applied. Otherwise, the two mentioned remaining methods are used (Balcerzak \& Pietrzak 2016a; 2016b).

After estimation, the model is verified in regard to the significance of parameters and a degree of fit of the obtained model to empirical data (Bollen, 1989; Kaplan, 2000). The verification of the model is based on the comparison of the obtained model with a saturated and an independent model. There are to most commonly applied measures for this purpose: IFI (Incremental Fit Index) and RMSEA (Root Mean Square Error of Approximation).

The values of the IFI measure should fulfill the condition $0<I F I<1$. In the case of models which are based on the survey data, it is commonly assumed that its value should be higher than 0,9 , which means that the model can be considered as the one with sufficient fit to empirical data. 
ENTREPRENEURSHIP AND SUSTAINABILITY ISSUES

ISSN 2345-0282 (online) http://jssidoi.org/jesi/

2017 Volume 5 Number 2 (December)

http://doi.org/10.9770/jesi.2017.5.2(2)

For RMSEA measure it is assumed that the lower value of the RMSA estimated for the given model, the better degree of the empirical model is obtained. Thus, it is commonly assumed that RMSA $<0,1$ indicates that the model is well fitted to empirical data.

However, it should be emphasised that in the case of models estimated for aggregated data obtained from macroeconomic or regional statistics, the above mentioned limits are usually less restrictive (Balcerzak \& Pietrzak 2016a; 2016b).

Based on the previous preliminary research of the authors (see Pietrzak \& Balcerzak, 2016c; Pietrzak, 2017) the following two empirical hypotheses were proposed:

1. In the years 2010-2014 the quality of entrepreneurial environment in Polish regions has improved.

2. Significant disparities of quality of entrepreneurial conditions between central and peripheral regions in Poland are relatively stable in time.

\section{The empirical model}

The research study was devoted to the measurement of quality of entrepreneurial environment at regional (NUTS 2) level in Poland in the year 2010 and 2014. The short period of the analysis is restricted with the comparable data at regional level, which is provided by Central Statistical Office of Poland. The data were available in two bases: Local Data Bank (https://bdl.stat.gov.pl/BDL/start\#) and Sustainable Development Indicators / Regional module (http://wskaznikizrp.stat.gov.pl/).

The three assumed pillars of quality of entrepreneurial environment at regional level, which were the theoretical base for selection of potential diagnostic variables, are given at figure 1. The pillars were indetified on the basis of the previous literature review in the field (see more Pietrzak \& Balcerzak, 2016c; Pietrzak, 2017). One can expect that there are interrelations between the pointed pillars. However, in current model, which should enable to assess the applicability of the separate diagnostic variables for measurement purposes, these potential interrelations were not modeled deliberately. As a result table 1 provides specific information on the diagnostic variables applied for the model. The diagnostic variables were classified as stimulants and dis-stimulants. The stimulants fulfill the condition: $x_{i, j}^{s}>x_{k, j}^{s} \rightarrow O_{i} \succ O_{k}$ for $X_{j}^{s}$ for every two values $x_{i, j}^{s}, x_{k, j}^{s}$ that refer to objects $O_{\mathrm{i}}$, $O_{\mathrm{k}}$, where $\succ$ means that object $O_{\mathrm{i}}$ is preferred to $O_{\mathrm{k}}$. Thus, for stimulants a maximum value of variable is preferred. The dis-stimulants fulfill the condition: $x_{i, j}^{s}<x_{k, j}^{s} \rightarrow O_{i} \prec O_{k}$ for $X_{j}^{s}$ for every two values $x_{i, j}^{s}, x_{k, j}^{s}$ that refer to objects $O_{i}, O_{k}$, where $\prec$ means that object $O_{k}$ is preferred to object $O_{i}$. This means that a minimum value of variable is preferred (Balcerzak \& Pietrzak, 2016b; Kruk \& Waśniewska, 2017).

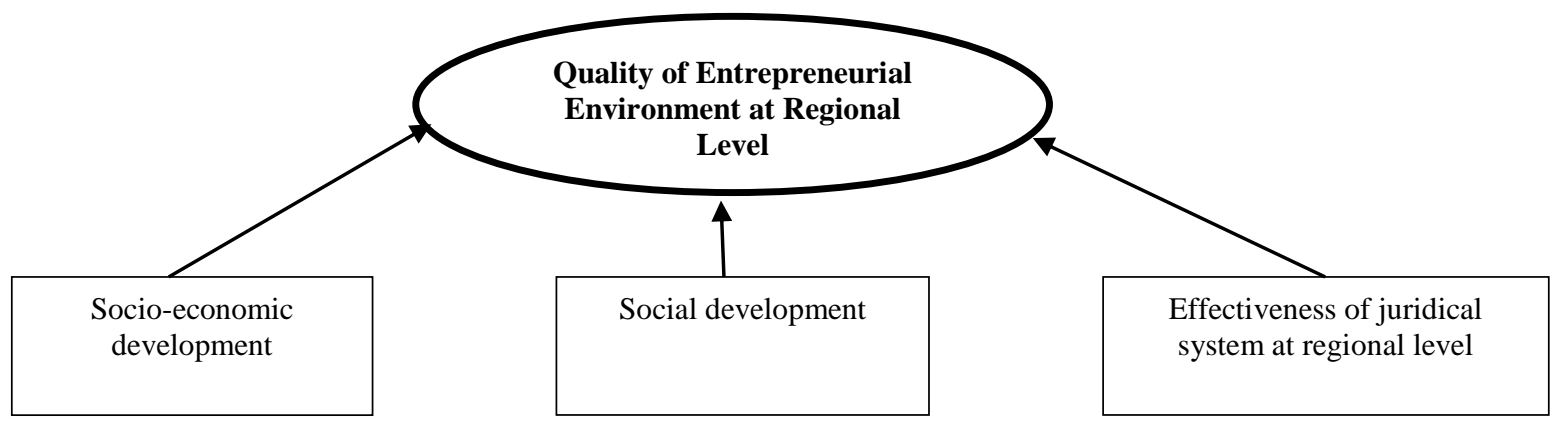

Fig. 1. Factors influencing quality of entrepreneurial environment at regional level

Source: own work 
Table 1. A set of factors affecting quality of entrepreneurship environment within sustainability framework

\begin{tabular}{|c|c|}
\hline \multicolumn{2}{|l|}{ Socio-economic development } \\
\hline \multicolumn{2}{|l|}{ Area 1- Fundamental economic conditions } \\
\hline $\begin{array}{l}\mathrm{X}_{1}-\text { Gross domestic product per capita at regional level. It presents the final result of the activity of all entities of the national } \\
\text { economy. GDP is the sum of gross value added generated by all national institutional units, increased by taxes on products and } \\
\text { decreased by subsidies on products. }\end{array}$ & stimulant \\
\hline $\begin{array}{l}\mathrm{X}_{2} \text { - Investments outlays per capita. It presents the value of total investment expenditure in the private and public sector per } 1 \\
\text { inhabitant. Investment expenditures include financial or material outlays which aim is to create new fixed assets or improve } \\
\text { (extension, reconstruction or modernization) of existing objects of fixed assets, as well as expenditure on so-called first } \\
\text { investment equipment. }\end{array}$ & stimulant \\
\hline \multicolumn{2}{|l|}{ Area 2 - Effectivness of labour market } \\
\hline $\begin{array}{l}\mathrm{X}_{3}-\text { Employment rate by age. It shows the share of total employed in the total population of a given category aged } 15 \text { and more } \\
\text { (average annual data based on Labour Force Survey (see detailed explanation for } \mathrm{X}_{4} \text { variable). }\end{array}$ & stimulant \\
\hline $\begin{array}{l}\mathrm{X}_{4} \text { - Unemployment rate (Labour Force Survey). It is a representative survey conducted on a quarterly basis using the continuous } \\
\text { observation method, which means that economic activity is examined each week throughout the entire quarter (in each of the } 13 \\
\text { weeks of the quarter } 1 / 13 \text { part of the quarterly sample). The results from the sample are generalized to the whole population based } \\
\text { on the national census. The results of quarterly surveys are translated into average data for the year. The study covers persons } \\
\text { aged } 15 \text { and more who are members of households - the study does not cover persons staying outside the household (eg they were } \\
\text { abroad) } 12 \text { months or more (up to 2Q } 2012 \text { it was over } 3 \text { months. }\end{array}$ & $\begin{array}{l}\text { dis- } \\
\text { stimulant }\end{array}$ \\
\hline \multicolumn{2}{|l|}{ Area 3- Innovativeness } \\
\hline $\begin{array}{l}\mathrm{X}_{5}-\text { Expenditure on R\&D activity in relation to GDP. Research and development (R \& D) is a systematic creative work carried } \\
\text { out in order to increase the stock of knowledge and to find new uses for this knowledge). }\end{array}$ & stimulant \\
\hline \multicolumn{2}{|l|}{ Social development } \\
\hline \multicolumn{2}{|l|}{ Area 1 - Demography } \\
\hline $\begin{array}{l}\mathrm{X}_{6}-\text { Ratio of balance of permanent migration person at working age (Intervoivodship migration). It is a difference between } \\
\text { inflow (immigration) and outflow (emigration) of the population for permanent residence in relation to the working-age } \\
\text { population. }\end{array}$ & stimulant \\
\hline \multicolumn{2}{|l|}{ Area 2 - Poverty and Social Exclusion } \\
\hline $\begin{array}{l}\mathrm{X}_{7}-\text { At-risk-of-poverty rate after social transfers. The percentage of people whose disposable income (when taken into account } \\
\text { social transfers) is less than the poverty line of } 60 \% \text { of median equivalent disposable income in a given country. }\end{array}$ & $\begin{array}{l}\text { dis- } \\
\text { stimulant }\end{array}$ \\
\hline $\begin{array}{l}\mathrm{X}_{8}-\text { People in households benefiting from the social assistance at domicile in percentage of the total population. Measured as the } \\
\text { share of people in households benefiting from community social support in the general population. The community social } \\
\text { assistance is granted as financial, material assistance or assistance in the form of service aid through a social assistance center. }\end{array}$ & $\begin{array}{l}\text { dis- } \\
\text { stimulant }\end{array}$ \\
\hline $\begin{array}{l}\mathrm{X}_{9}-\text { Average monthly available income per capita in private households. Household disposable income is the sum of current } \\
\text { household income from individual sources minus the value of taxes and the value of social security and health insurance } \\
\text { contributions. }\end{array}$ & stimulant \\
\hline \multicolumn{2}{|l|}{ Area 3 - Education } \\
\hline $\begin{array}{l}\mathrm{X}_{10} \text { - Adult persons participating in education and training. Measured as the share of people aged 25-64 studying and training in } \\
\text { the total population in the same age group (within four weeks before the survey - Labour Force Survey). }\end{array}$ & stimulant \\
\hline $\mathrm{X}_{11}-$ Children covered by pre-school education in percentage of the total number of children at the age 3-5 & stimulant \\
\hline \multicolumn{2}{|l|}{ Effectiveness of juridical system } \\
\hline $\begin{array}{l}\mathrm{X}_{12} \text { - Rate of detectability of the delinquents of ascertained crimes. The index is calculated as the ratio of the number of crimes } \\
\text { detected in a given year (including those detected after redemption) to the number of offenses found in a given year, plus the } \\
\text { number of offenses identified in the proceedings and remitted in previous years due to non-detection of perpetrators. }\end{array}$ & stimulant \\
\hline
\end{tabular}

Note: a precise description of the variables and the methodology for data collection is available at http://wskaznikizrp.stat.gov.pl/. 
Based on the diagnostic variables from table 1 confirmatory factor analysis was conducted. For the selected diagnostic variables Alfa-Cronbacha (see Cronbach, 1951) coefficient was assessed. The value of Alfa-Cronbacha equal to 0,71 for the twelve pointed diagnostic variables indicates that the diagnostic variables should properly describe the latent variable. The hypothetic SEM model applied in the research study is given in figure 2.

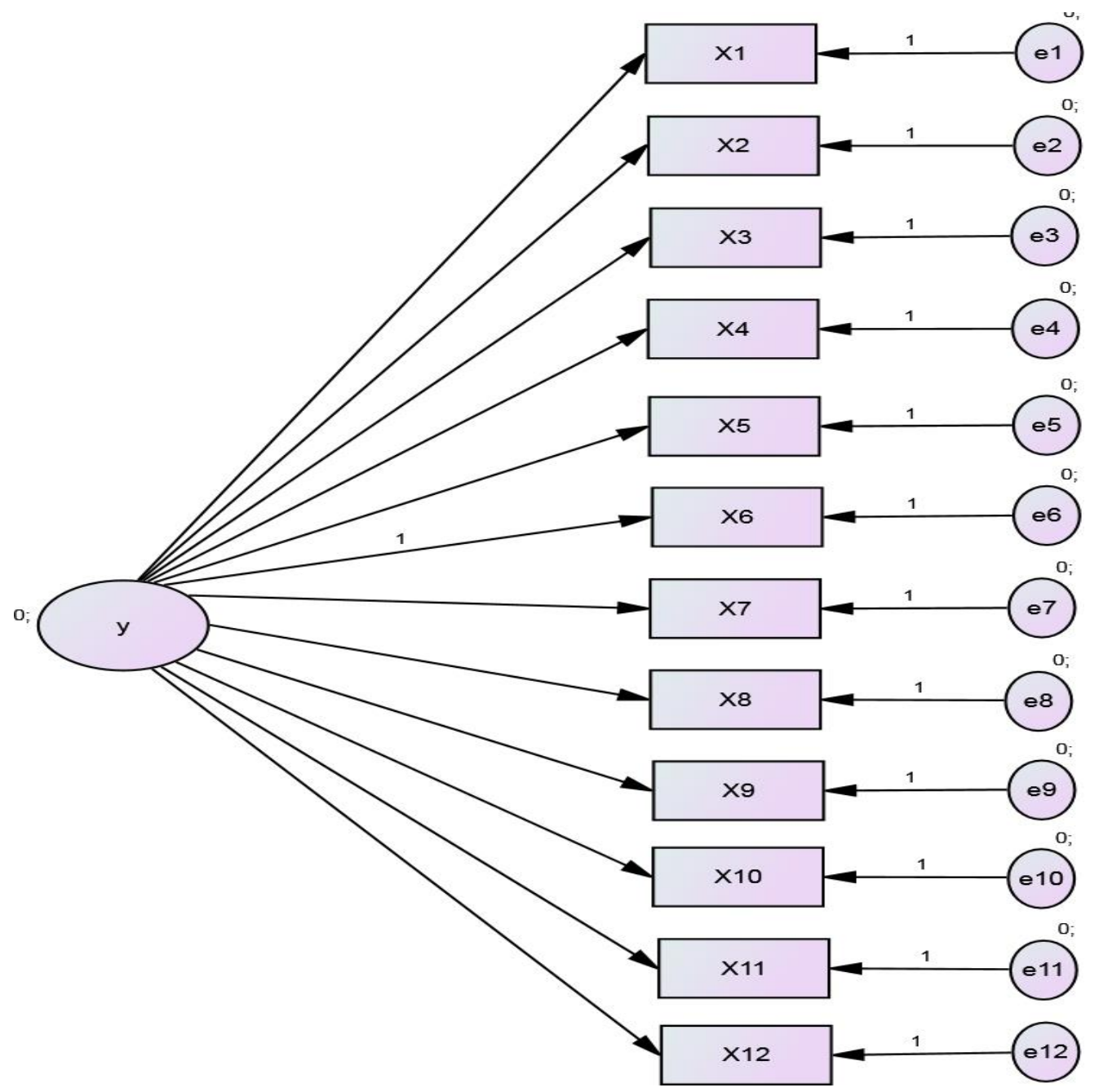

Fig. 2. Hypothetic SEM model for estimation of quality of entrepreneurial environment at regional level in Poland

Source: own elaboration

The estimation of the parameters of the model was done in the AMOS package. In the case this research study some of the variables did not fulfill the condition of normal distribution. Thus, in order to estimate the parameters of the model, asymptotically distribution-free (ADF) method was used. The results of the estimation procedure are given in Table 2. 
ENTREPRENEURSHIP AND SUSTAINABILITY ISSUES

ISSN 2345-0282 (online) http://jssidoi.org/jesi/

2017 Volume 5 Number 2 (December)

http://doi.org/10.9770/jesi.2017.5.2(2)

Table 2. Estimations of parameters of SEM model for quality of entrepreneurial environment at regional level

\begin{tabular}{|c|c|r|r|c|}
\hline Variable & Parameter & \multicolumn{1}{|c|}{ Estimate } & Standardized estimate & p-value \\
\hline$X_{1}$ & $\alpha_{1}$ & 44.907 & 0.934 & $\sim 0.00$ \\
\hline$X_{2}$ & $\alpha_{2}$ & 4.853 & 0.807 & $\sim 0.00$ \\
\hline$X_{3}$ & $\alpha_{3}$ & 6.929 & 0.635 & $\sim 0.00$ \\
\hline$X_{4}$ & $\alpha_{4}$ & 1 & 0.597 & - \\
\hline$X_{5}$ & $\alpha_{5}$ & 70.307 & 0.844 & $\sim 0.00$ \\
\hline$X_{6}$ & $\alpha_{6}$ & -11.982 & -0.548 & $\sim 0.00$ \\
\hline$X_{7}$ & $\alpha_{7}$ & -7.085 & -0.655 & $\sim 0.00$ \\
\hline$X_{8}$ & $\alpha_{8}$ & 682.236 & 0.889 & $\sim 0.00$ \\
\hline$X_{9}$ & $\alpha_{9}$ & 3.356 & 0.591 & $\sim 0.00$ \\
\hline$X_{10}$ & $\alpha_{10}$ & 16.569 & 0.527 & $\sim 0.00$ \\
\hline$X_{11}$ & $\alpha_{11}$ & -4.383 & -0.584 & $\sim 0.00$ \\
\hline$X_{12}$ & $\alpha_{12}$ & 17.468 & 0.715 & $\sim 0.00$ \\
\hline Model & IFI & RMSEA & & \\
\hline Default & 0.766 & 0.194 & & \\
\hline Independence & 0.000 & 0.359 & & \\
\hline
\end{tabular}

Source: own estimation based on data form Central Statistical Office of Poland: Local Data Bank (https://bdl.stat.gov.pl/BDL/start\#) and Sustainable Development Indicators / Regional module (http://wskaznikizrp.stat.gov.pl/)

The parameters of the estimated model are statistically significant. It can indicate proper selection of diagnostic variables for the latent variable. The verification of the quality of the model in regard to the degree of fit to empirical data was based on IFI and RMSEA measures, which are also given in table 2. In that case IFI was equal to 0,766 , and RMSEA was equal to 0,194 . In spite of the fact that these values do not fulfill the limits usually applied for SEM models based on survey data, they can be accepted in the case of models for aggregated data from official national statistics.

Table 3. Factor Score Weights for the SEM model

\begin{tabular}{|c|c|c|c|c|c|c|}
\hline \multirow{2}{*}{ Latent variable } & \multicolumn{6}{|c|}{ Observable variables } \\
\cline { 2 - 7 } & $X_{1}$ & $X_{2}$ & $X_{3}$ & $X_{4}$ & $X_{5}$ & $X_{6}$ \\
\hline \multirow{3}{*}{ Socio-economic development } & 0.021 & 0.054 & 0.081 & 0.015 & 0.006 & -0.006 \\
\cline { 2 - 8 } & $X_{7}$ & $X_{8}$ & $X_{9}$ & $X_{10}$ & $X_{11}$ & $X_{12}$ \\
\cline { 2 - 8 } & -0.015 & 0.001 & 0.024 & 0.003 & -0.018 & 0.009 \\
\hline
\end{tabular}

Source: own estimation 
In the next step of the research the values of latent variable (quality of entrepreneurial environment at regional level) for the year 2010 and 2014 were assessed based on the sum of product of values of Factor Score Weights (table 3 ) and the values of observable variables. Based on the obtained results it was possible to propose a ranking of the NUTS 2 regions for both years (see table 4). Additionally, with application of Natural Breaks method the regions were grouped into four relatively homogenous classes, where class four includes the NUTS 2 regions with the best entrepreneurial environment, while class 1 encompass these which achieved worst results. The final results are presented in table 4 and figure 3.

Table 4. Ranking and grouping of NUTS 2 regions in regard to quality of entrepreneurship environment

\begin{tabular}{|c|c|c|c|c|c|c|c|}
\hline \multicolumn{8}{|c|}{ Quality of entrepreneurial environment at regional level in Poland } \\
\hline \multicolumn{4}{|c|}{2010} & \multicolumn{4}{|c|}{2014} \\
\hline NUTS 2 region & SEM & rank & class & NUTS 2 region & SEM & rank & class \\
\hline mazowieckie & 0.744 & 1 & 4 & mazowieckie & 0.925 & 1 & 4 \\
\hline wielkopolskie & 0.425 & 2 & 3 & dolnośląskie & 0.576 & 2 & 3 \\
\hline dolnośląskie & 0.423 & 3 & 3 & pomorskie & 0.519 & 3 & 3 \\
\hline śląskie & 0.422 & 4 & 3 & wielkopolskie & 0.500 & 4 & 3 \\
\hline pomorskie & 0.410 & 5 & 3 & małopolskie & 0.468 & 5 & 3 \\
\hline małopolskie & 0.394 & 6 & 3 & śląskie & 0.464 & 6 & 3 \\
\hline łódzkie & 0.356 & 7 & 3 & łódzkie & 0.449 & 7 & 3 \\
\hline lubuskie & 0.309 & 8 & 2 & opolskie & 0.369 & 8 & 2 \\
\hline opolskie & 0.303 & 9 & 2 & zachodniopomorskie & 0.359 & 9 & 2 \\
\hline kujawsko-pomorskie & 0.276 & 10 & 2 & kujawsko-pomorskie & 0.311 & 10 & 2 \\
\hline zachodniopomorskie & 0.254 & 11 & 2 & podlaskie & 0.307 & 11 & 2 \\
\hline podlaskie & 0.226 & 12 & 1 & lubuskie & 0.301 & 12 & 2 \\
\hline świętokrzyskie & 0.187 & 13 & 1 & podkarpackie & 0.238 & 13 & 1 \\
\hline podkarpackie & 0.184 & 14 & 1 & lubelskie & 0.222 & 14 & 1 \\
\hline lubelskie & 0.180 & 15 & 1 & warmińsko-mazurskie & 0.208 & 15 & 1 \\
\hline warmińsko-mazurskie & 0.163 & 16 & 1 & świętokrzyskie & 0.190 & 16 & 1 \\
\hline
\end{tabular}

Source: own estmation based on data form Central Statistical Office of Poland: Local Data Bank (https://bdl.stat.gov.pl/BDL/start\#) and Sustainable Development Indicators / Regional module (http://wskaznikizrp.stat.gov.pl/) 


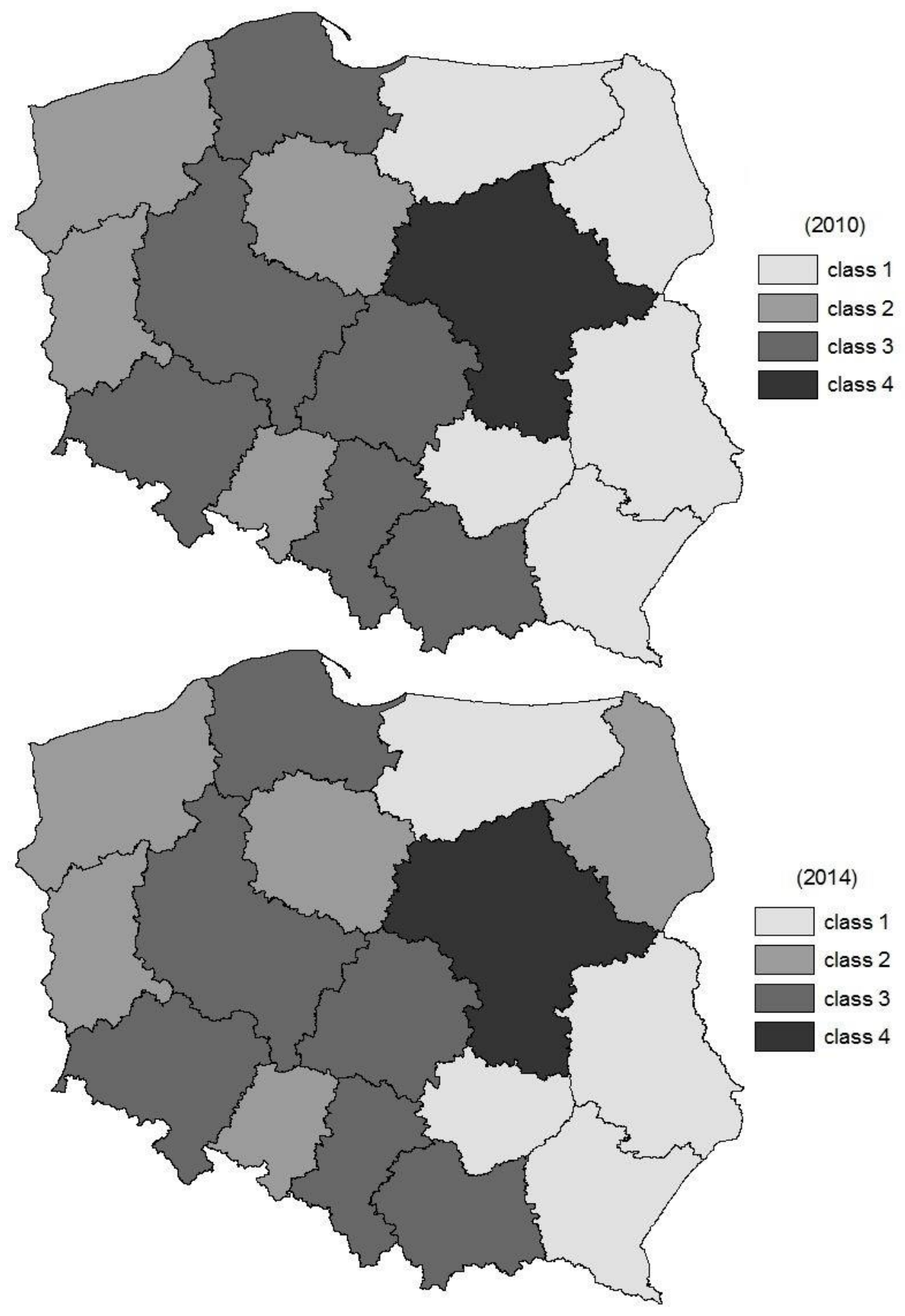

Fig 3. The NUTS 2 regions grouped based on quality of enterprenerial environment in Poland in the years 2010 and 2014

Source: own estmation based on data form Central Statistical Office of Poland: Local Data Bank (https://bdl.stat.gov.pl/BDL/start\#) and Sustainable Development Indicators / Regional module (http://wskaznikizrp.stat.gov.pl/). 


\section{Results}

Based on the obtained results it can be concluded the quality of entrepreneurial environment at regional level has generally improved. This positive picture can be seen in the differences in grouping the regions in the year 2010 and 2014. In the first year of the analysis in the first class there were five NUTS 2 regions, whereas in the last year of the research only four regions could be found. Thus, one should stress the progress obtained by the podlaskie region, which managed to move from the first class in the year 2010 to the second class in the year 2014. In the case of the region with the best conditions for entrepreneurship in both years one can find mazowieckie NUTS 2 region, which in both years of the research makes the class 4 . This region with the capital city metropolis is also considered as the best economically developed part of Poland. In the third class with relatively high quality of enterpenerial environment one can find dolnośląskie, wielkopolskie, pomorskie, łódzkie, śląskie and małopolskie NUTS 2 reions. In the year 2014 in the second class with average quality of entrepreneurial environment there are the following NUTS 2 regions zachodniopomorskie, podlaskie, opolskie, kujawsko-pomorskie and lubuskie. In the first class with the worst conditions for entrepreneurship in the year 2014 one could find warmińsko-mazurskie, podkarpackie, lubelskie and świętokrzyskie NUTS 2 regions.

\section{Discussion}

As it has been already mentioned in the previous section the obtained results confirmed that in the analyzed period the quality of entrepreneurial environment at regional level has significantly improved, which enables to confirm the first hypothesis of the research. It is especially important when one takes into consideration the fact the analyzed period has been still influenced by the negative consequences of the global financial crisis from the years 2008-2009.

However, one should also stress that in spite of this progress there are still significant disparities at regional level, which can be seen especially in the level of obtained value for the latent variable in both analyzed years. This result is consistent with the previous research of the authors in the field (see Pietrzak, 2017; Pietrzak. M. B. \& Balcerzak, 2016c) and recent research on the convergence process at national and regional level conducted by Kuc (2017b). The results can be considered as strong arguments in favour of the second empirical hipotehes of the article. The empirical contribution can indicate significant challenges for Polish policy makers and decision makers at regional level, as the constant disparities between the regions can be the source of instability of the whole economy and the factor negatively influencing its growth potential. In longer run that situation negatively affects socio-economic sustainability of the whole economy.

\section{Conclusions}

The presented research study was devoted to the problem of quality of entrepreneurial environment at regional level in Poland in the context of regional sustainability framework. In the research structural equation modeling was applied. From the methodological perspective most of the research in the field is based on taxonomic or multiple-criteria analysis tools. However, this research due to applying SEM methodology treats the analysed phenomenon as a latent variable, which can be considered as a value added in the field. Additionally, it enables to assess the applicability of potential diagnostic variables in the research concerning quality of entrepreneurial environment at regional level, which can be important information for standard multiple-criteria and taxonomic research, where the selection of diagnostic variable is arbitral or is based on taxonomic information value criteria.

However, one should be aware of important litmitation of curent empirical proposal. First of all, the choice of the diagnostic variables used in the research can be the source of discussion and critics. However, this factor is mostly the result of availability of comparable data at regional level, which can be the source of important information in the given sphere. The second most important limitation of the research is attributed to the short period of the empirical analysis, which is mostly the result of availability of comparable data at regional level. 
ENTREPRENEURSHIP AND SUSTAINABILITY ISSUES

ISSN 2345-0282 (online) http://jssidoi.org/jesi/

2017 Volume 5 Number 2 (December)

http://doi.org/10.9770/jesi.2017.5.2(2)

There are also important possibilities for future research in the field. First of all, as it was mentioned one should be aware that there are interrelations between the pillars of quality of entrepreneurship environment at regional level: a) socio-economic development, b) social development, c) quality of juridical system, which were not analysed in the current article. This empirical gap should be the next step in the modelling process of changes in the case of entrepreneurial environment in Poland.

The second direction of empirical research could be found in the comparison of the results obtained based on aggregated data form national statistics as it was done in current analysis, with a perception of entrepreneurial environment at regional level measured with application of survey research conducted among entrepreneurs.

\section{References}

Adamowicz, M., Machla, A. 2016. Small and medium enterprises and the support policy of local government, Oeconomia Copernicana 7(3): 405-437. https://doi.org/10.12775/OeC.2016.024

Agenor, P.-R., Canuto O., Jelenic, M. 2012. Avoiding Middle-Income Growth Traps, Economic Premise, Poverty Reduction and Economic Management Network, the World Bank, No. 98, November

Agenor, P.-R., Canuto O. 2015. Middle-income growth traps, Research in Economics 69(4): 641-660. https://doi.org/10.1016/j.rie.2015.04.003

Agrawal, R. 2016. 'Enterprise Risk Management' Essential for Survival and Sustainable Development of Micro, Small and Medium Enterprises, International Review, 1-2: 117-123

Balcerzak, A. P. 2016a. Multiple-criteria Evaluation of Quality of Human Capital in the European Union Countries, Economics \& Sociology 9(2): 11-27. https://doi.org/10.14254/2071-789X.2016/9-2/1

Balcerzak, A. P. 2016b. Fiscal Burden in the European Union Countries, Economic Annals XXI 161(9-10): 4-6. https://doi.org/10.21003/ea.V161-01

Balcerzak, A. P., Pietrzak, M. B. 2017. Digital Economy in Visegrad Coutnries. Multiple-criteria decision analysis at Regional Level in the Years 2012 and 2015, Journal of Competitiveness 9(2): 5-18. https://doi.org/10.7441/joc.2017.02.01

Balcerzak, A. P., Pietrzak, M. B. 2016a. Structural Equation Modeling in Evaluation of Technological Potential of European Union Countries in the Years 2008-2012, in Papież, M. \& Śmiech, S. (Eds.). The 10th Professor Aleksander Zelias International Conference on Modelling and Forecasting of Socio-Economic Phenomena. Conference Proceedings. Cracow: Foundation of the Cracow University of Economics, 9-18

Balcerzak, A. P., Pietrzak, M. B. 2016b. Quality of Human Capital in European Union in the Years 2004-2013. Application of Structural Equation Modeling, in Reiff, M. \& Gezik, P. (Eds.). Proceedings of the International Scientific Conference Quantitative Methods in Economics Multiple Criteria Decision Making XVIII. Vratna: Letra Interactive, 7-12

Balcerzak, A. P., Pietrzak, M. B. 2016c. Quality of Institutions for Knowledge-based Economy within New Institutional Economics Framework. Multiple Criteria Decision Analysis for European Countries in the Years 2000-2013, Economics \& Sociology 9(4): 66-81. https://doi.org/10.14254/2071-789X.2016/9-4/4

Bartkowiak-Bakun, N. 2017. The diversity of socioeconomic development of rural areas in Poland in The Western Borderland and the problem of post-state farm localities, Oeconomia Copernicana 8(3): 417-431. https://doi.org/https://doi.org/10.24136/oc.v8i3.26

Bollen, K. A 1989. Structural Equations with Latent Variables. Wiley

Brown, T. A. 2006. Confirmatory Factor Analysis for Applied Research. Guilford Press

Cronbach, L. J. 1951. Coefficient alpha and the internal structure of tests, Psychometrika 16(3): 297-334 
Czarniewski, S. 2016. Small and Medium-Sized Enterprises in the Context of Innovation and Entrepreneurship in the Economy, Polish Journal of Managemnet Studies 13(1): 30-39. https://doi.org/10.17512/pims.2016.13.1.03

Davis T. 2008. Understanding Entrepreneurship: Developing Indicators for International Comparisons and Assessments. in: Congregado E. (eds). Measuring Entrepreneurship. International Studies in Entrepreneurship, vol 16. Boston: Springer, 39-63.

Dobeš, K., Kot, S., Kramoliš, J., \& Sopková, G. 2017. The Perception of Governmental Support in the Context of Competitiveness of SMEs in the Czech Republic, Journal of Competitiveness 9(3): 34-50. https://doi.org/10.7441/joc.2017.03.03

Gajdos, A. 2014. Spatial Analysis Of Human Capital Structures, Comparative Economic Research . Central and Eastern Europe 17: 43-54

Gajdos, A., Żmurkow-Poteralska, E. 2012. Skilled Personnel Supply and The Prospects for Regional Innovative Development in Poland, Comparative Economic Research, Central and Eastern Europe 4: 45-58

Ivanová, E. 2017. Barriers to the development of SMEs in the Slovak Republic, Oeconomia Copernicana 8(2): 255-272. https://doi.org/10.24136/oc.v8i2.16

Kaplan, D. 2000. Structural Equation Modeling: Foundations and Extensions. Sage Publications

Kawiorska, D. 2016. Healthcare in the light of the concept of welfare state regimes - comparative analysis of EU member states, Oeconomia Copernicana 7(2): 187-206. https://doi.org/10.12775/OeC.2016.012

Kljucnikov, A., Belas, J. 2016. Approaches of Czech entrepreneurs to debt financing and management of credit risk. Equilibrium. Quarterly Journal of Economics and Economic Policy 11(2): 343-365. https://doi.org/10.12775/EQUIL.2016.016

Ključnikov A., Belás J., Kozubíková L., Paseková P. 2016. The Entreprenurial Perception of SME Business Environment Quality in the Czech Republic, Journal of Competitiveness 8(1): 66-78. https://doi.org/10.7441/joc.2016.01.05

Knatko, D., Shirokova, G., Bogatyreva, K. 2016. Industry choice by young entrepreneurs in different country settings: the role of human and financial capital, Journal of Business Economics and Management, 17(4): 613-627. https://doi.org/10.3846/16111699.2015.1113199

Kondratiuk-Nierodzińska, M. K.-N. 2016. New knowledge generation capabilities and economic performance of Polish regions. Equilibrium. Quarterly Journal of Economics and Economic Policy 11(3): 451-471. https://doi.org/10.12775/EQUIL.2016.021

Kooshki, S., A., Zeinabadi, H. 2016. The role of organizational virtuousness in organizational citizenship behavior of teachers: the test of direct and indirect effects through job satisfaction mediating, International Review, 1-2: 7-21

Kot, S., Meyer, N., Broniszewska, A. 2016. A Cross-Country Comparison of the Characteristics of Polish and South African Women Entrepreneurs, Economics and Sociology 9(4): 207-221. https://doi.org/10.14254/2071-789X.2016/9-4/13

Kruk, H., Waśniewska, A. 2017. Application of the Perkal method for assessing competitiveness of the countries of Central and Eastern Europe, Oeconomia Copernicana 8(3): 337-352. https://doi.org/10.24136/oc.v8i3.21

Kuc, M. 2017a. Social convergence in Nordic countries at regional level, Equilibrium. Quarterly Journal of Economics and Economic Policy 12(1): 25-41. https://doi.org/10.24136/eq.v12i1.2

Kuc, M. 2017b. Is regional divergence price for the international convergence? The case of the Visegrad Group, Journal of Competitiveness 9(4): 50-65. https://doi.org/10.7441/joc.2017.04.04

Kuc, M. 2014. Social convergane in the European Union. n Papież, M. \& Śmiech, S. (Eds.). Proceedings of the $8^{\text {th }}$ Professor Aleksander Zelias International Conference on Modelling and Forecasting of Socio-Economic Phenomena. Cracow: Foundation of the Cracow University of Economics, 105-114

Kozubíková L., Homolka L., Kristalas, D. 2017. The Effect of Business Environment and Entrepreneurs' Gender on Perception of Financial Risk in the SMEs Sector, Journal of Competitiveness 9(1): 36-50. https://doi.org/10.7441/joc.2017.01.03

Loehlin, J. C. 1987. Latent variable models: An introduction to factor, path and structural analysis. Erlbaum

Melas, V.; Lisin, E.; Tvaronavičienė, M.; Peresadko, G.; Radwański, R. 2017. Energy security and economic development: renewables and the integration of energy systems, Journal of Security and Sustainability Issues 7(1): 133-139. https://doi.org/10.9770/jssi.2017.7.1(11) 
ENTREPRENEURSHIP AND SUSTAINABILITY ISSUES

ISSN 2345-0282 (online) http://jssidoi.org/jesi/

2017 Volume 5 Number 2 (December)

http://doi.org/10.9770/jesi.2017.5.2(2)

Meyer, N., Meyer, D. F., Molefe, K. 2016. Barriers to Small Informal Business Development and Entrepreneurship: the Case of the Emfuleni Region, Polish Journal of Management Studies 13(1): 121-133. https://doi.org/10.17512/pjms.2016.13.1.12

Pietrzak, M. B. 2017. Structural Equation Modeling of Regional Economic Development in Polish Voivodeships in the Years 2010-2014. in Loster, T. \& Pavelka, T. (Eds.). The 11th International Days of Statistics and Economics. Conference Proceedings. September 8-10, 2016. Prague: Libuse Macakova, Melandrium, 1214-1222

Pietrzak, M. B., Żurek, M., Matusik, S., Wilk, J. 2012. Application of Structural Equation Modeling for analysing internal migration phenomena in Poland, Przegląd Statystyczny 59(4), 487-503

Pietrzak, M. B. \& Balcerzak, A. P. (2016a). A Spatial SAR Model in Evaluating Influence of Entrepreneurship and Investments on Unemployment in Poland. In M. Reiff \& P. Gezik (Eds.). Proceedings of the International Scientific Conference Quantitative Methods in Economics Multiple Criteria Decision Making XVIII. Vratna: Letra Interactive, 303-308

Pietrzak, M. B., Balcerzak, A. P. 2016b. Quality of Human Capital and Total Factor Productivity in New EU Member States. in Loster, T. \& Pavelka, T. (Eds.). The 10th International Days of Statistics and Economics. Conference Proceedings. September 8-10, 2016. Prague: Libuse Macakova, Melandrium, 1492-1501

Pietrzak. M. B., Balcerzak, A. P. 2016c. Socio-economic Sustainability in Poland. SEM Analysis at Regional Level. in Kliestik, T. (Ed.). 16th International Scientific Conference Globalization and Its Socio-Economic Consequences. University of Zilina, The Faculty of Operation and Economics of Transport and Communication, Department of Economics, 5th - 6th October 2016. (Part IV.). Zilina: University of Zilina, 1704-1712

Saeed, J. M., Reza, Z. M., Hadi, S. 2017. Entrepreneurship Development Policymaking Factors: An exploratory survey of Tourism in Iran, International Review, 1-2: 73-83

Smaliukienè, R., Chlivickas, E., Bekešienè, S., Magyla, M. 2017. Explicating the role of trust in knowledge sharing: a structural equation model test, Journal of Business Economics and Management, 18(4): 758-778. https://doi.org/10.3846/16111699.2017.1317019

Strielkowski, W.; Lisin, E.; Tvaronavičienè, M. 2016. Towards energy security: sustainable development of electrical energy storage, Journal of Security and Sustainability Issues 6(2): 43-52. http://dx.doi.org/10.9770/jssi.2016.6.2(4)

Yan T., Yay, G.G., Aksoy, T. 2017. Impact of institutions on entrepreneurship: a panel data analysis Euroasian Economic Review, Published online 9 September 2017, https://doi.org/10.1007/s40822-017-0082-0

Żelazny, R., Pietrucha, J. 2017. Measuring innovation and institution: the creative economy index. Equilibrium. Quarterly Journal of Economics and Economic Policy 12(1): 43-62. https://doi.org/https://doi.org/10.24136/eq.v12i1.3

Zemlickiene, V.; Mačiulis, A.; Tvaronavičienè, M. 2017. Factors impacting the commercial potential of technologies: expert approach, Technological and Economic Development of Economy, 23(2): 410-427 http://dx.doi.org/10.3846/20294913.2016.1271061

Michal Barnard PIETRZAK, PhD is a lecturer in the Department of Statisics and Econometrics at Nicolaus Copernicus University. He is a secretary of Polish Statistical Society Branch in Torun. He specialises in spatial econometrics.

ORCID ID: orcid.org/0000-0002-9263-4478

Adam P. BALCERZAK, PhD is a lecturer in the Department of Economics at Nicolaus Copernicus University. He is a chairman of Polish Economic Society Branch in Torun. Research interests: instituiotnal economics, influence of entrepreneurship on regional and macroeconomic productivity, determinants of sustainable growth, the role of financial markets in growth dynamics.

ORCID ID: orcid.org/0000-0003-0352-1373 
ENTREPRENEURSHIP AND SUSTAINABILITY ISSUES

ISSN 2345-0282 (online) http://jssidoi.org/jesi/

2017 Volume 5 Number 2 (December)

http://doi.org/10.9770/jesi.2017.5.2(2)

Artur GAJDOS, PhD is an assistant professor in the Department of Spatial Econometrics at the University of Lodz, Poland. He is the author (co-author) of several publications on modelling and forecasting the labour market. He has participated in many research projects on national and regional analyses of the labour market. He was a coordinator of the project Forecasting System for Labour Demand in Poland and he is a national expert for CEDEFOP. Research interests: labour market forecasting, occupational structure of the labour market, labour market polarisation, information systems, data visualization.

ORCID ID: https://orcid.org/0000-0001-8124-2703

Lukasz ARENDT, PhD is the Director of the Institute of Labour and Social Studies in Warsaw, and Assistant Professor in the Department of Economic Policy at the University of Lodz, Poland. He has been involved in international research projects, including these within PROGRESS programme, commissioned by DG EAC, and CEDEFOP. His research experience covers evaluation of PES capabilities, delivering proposal of the Polish flexicurity model, consultancy activities for the Polish Ministry of Family, Labour and Social Policy, and the Ministry of Regional Development. Research interests: emergence of the information society, enhancing SMEs growth by wider utilisation of ICT, labour market polarisation, education, training, and lifelong learning schemes.

ORCID ID: orcid.org/0000-0002-0596-0196

Copyright (C) 2017 by author(s) and VsI Entrepreneurship and Sustainability Center This work is licensed under the Creative Commons Attribution International License (CC BY). http://creativecommons.org/licenses/by/4.0/

(c) (1) Open Access 